\title{
Hepatic Solitary Fibrous Tumor Presenting as Severe Hypoglycaemia: A Case-Report
}

\author{
Thomas E. Manning1, Anna E. Manning2, Patrick J. Manning1* \\ ${ }^{1}$ Department of Medicine, Dunedin School of Medicine, Dunedin, New Zealand \\ ${ }^{2}$ Tauranga Hospital, Tauranga, New Zealand \\ Email: * patrickmanning@healthotago.co.nz
}

Received 23 January 2015; accepted 5 February 2015; published 11 February 2015

Copyright (C) 2015 by authors and Scientific Research Publishing Inc.

This work is licensed under the Creative Commons Attribution International License (CC BY). http://creativecommons.org/licenses/by/4.0/

c) (i) Open Access

\section{Abstract}

We report a case of a patient presenting with profound insulin-independent hypoglycaemia. A large hepatic leasion was identified and surgically resected. Histology confirmed a $17.5 \mathrm{~cm}$ hepatic solitary fibrous tumour. The clinical and biochemical presentation is consistent with IGF-II mediated hypoglycaemia.

\section{Keywords}

Hepatic Solitary Fibrous Tumour, IGF-II Mediated Hypoglycaemia, Hepatomegaly, Hypoglycaemia

\section{Introduction}

Hypoglycemia in adults without diabetes is uncommon. Multiple possible etiologies have been described including islet and non-islet cell tumors, medications, alcohol, sepsis, organ failure and cortisol deficiency. Numerous tumor types have been associated with non-islet cell tumor hypoglycemia (NICTH) including tumors of mesenchymalor gastrointestinal origin [1]. Solitary fibrous tumors (SFTs) are rare neoplasms and are usually found in the thorax arising from the pleura. Here we report a case of a SFT of the liver causing NICTH.

\section{Case Description}

A 45-year-old male presented with recurrent episodes of mild confusion, sweating and tremor for 2 weeks, all of which were relieved by eating. On the day of admission he was found by his wife significantly confused and medical attention was sought. A neurological disorder was initially considered the most likely explanation for his presentation, however a capillary blood glucose concentration showed hypoglycemia and treatment with oral

"Corresponding author.

How to cite this paper: Manning, T.E., Manning, A.E. and Manning, P.J. (2015) Hepatic Solitary Fibrous Tumor Presenting as Severe Hypoglycaemia: A Case-Report. Case Reports in Clinical Medicine, 4, 60-62. 
glucose promptly improved his symptoms. The patient was subsequently admitted to hospital for further investigation for hypoglycemia. He did not have diabetes nor access to hypoglycemic medications. His weight was 88 $\mathrm{kg}$ and blood pressure 130/60 mmHg. Routine clinical examination was unremarkable apart from evidence of hepatomegaly. A mental status and full neurological examinations were normal. Liver function tests, tumor markers and hepatitis serology were normal. A 72-hour fast was commenced and the patient became symptomatically hypoglycemic after 6 hours of fasting. His biochemical results at this time are shown in Table 1 .

Tests of adrenal function and growth hormone production were normal. The insulin like growth factor- 1 concentration was $18 \mu \mathrm{g} / \mathrm{L}$ (Standard Deviation Score < -5.0). Insulin-independent hypoglycemia was diagnosed and the suppressed IGF-1 concentration suggested ectopic production of IFG-2 as the responsible mechanism. The patient was encouraged to increase his calorie intake and eat more frequently. This successfully prevented further hypoglycemic episodes. A CT scan of the abdomen revealed an $18 \mathrm{~cm}$ vascular mass arising from segments 5 and 6 of the liver (Figure 1).

The patient required in situ right portal vein ligation and liver split prior to definitive resection of the hepatic mass by extended right hepatectomy. The patient made an uneventful recovery from surgery and has not had any further episodes of hypoglycemia.

The tumor had a predominantly flesh colored cut surface with islands of necrotic material and focal areas of hemorrhage. On microscopic inspection the tumor consisted of spindled cells with intervening collagen fibers. Staghorn vessels were seen at the edge of the lesion. There was moderate cellular atypia and vascular invasion present. Up to 5 mitoses per 10 high powered field were seen and the ki67 was $8 \%$. The findings were consistent with those of a malignant solitary fibrous tumor.

\section{Discussion}

Solitary fibrous tumor, previously called hemangiopericytoma, belongs to a spectrum of neoplasms derived from a single family of mesenchymal tumours that are fibroblastic in nature with a prominent branching vascular

\begin{tabular}{ccc} 
Table 1. Results of biochemical investigations. & \\
\hline & Result & Reference \\
\hline Plasma glucose (mmol/L) & 2.2 & $3.5-6.0$ \\
Insulin (pmol/L) & $<3$ & $10-80$ \\
C-Peptide (pmol/L) & 30 & $350-750$ \\
Beta-hydroxybutyrate (mmol/L) & 0.1 & $<0.3$ \\
Plasma sulphonylurea screen & Undetected & \\
\hline
\end{tabular}

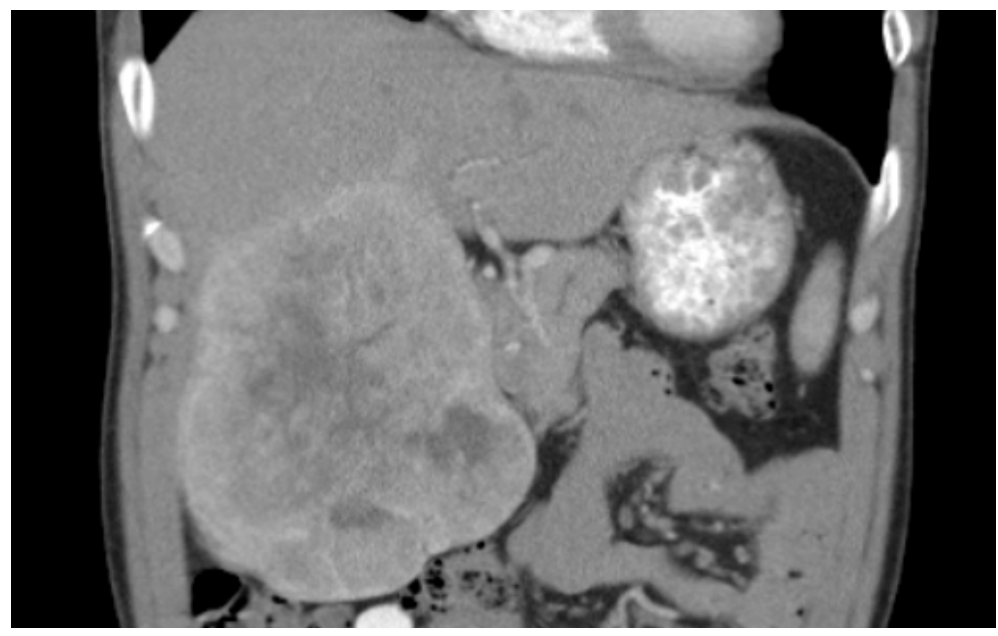

Figure 1. Contrast enhanced CT scan of the liver (coronal section) revealing large $(18 \mathrm{~cm})$ solitary hepatic lesion. 
pattern [2]. Contrary to what its name suggests, SFT is not a tumor of pericytic origin and is currently classed as a mesenchymal neoplasm of unknown origin. The majority of SFTs arise from either pleural tissue or soft tissues of the lower extremity [3].

Hepatic SFTs are very rare with approximately only 42 reported cases, 4 of those being malignant [4]. One longitudinal analysis found that $90 \%$ of patients with hepatic SFT presented with a painless, enlarging mass in their upper right quadrant [5]. Approximately a quarter of patients with SFT also develop hypoglycaemia [6]. This paraneoplastic syndrome seems to be a function of SFTs reliance on overexpression of insulin-like growth factor II (IGF-II) to achieve its continuing growth. IGF-II is predominantly synthesised in the liver for fetal growth regulation and cellular proliferation. However, it is also utilised by SFTs to promote mitogenesis, malignancy transformation, and differentiation [2]. In addition, approximately $90 \%$ of SFTs produce ectopic IGF-I receptor which facilitates the action of IGF-II [6]. The hypoglycemia reported with ectopic IGF-II production is related to IGF-II binding to and activating the insulin receptor. The resultant hypoglycemia results in appropriate suppression of insulin and C-peptide production. Raised IGF-II concentrations can also bind to the IGF-I receptor causing suppression of growth hormone and subsequently IGF-I levels as seen in our patient. This is a useful clue as to the presence of ectopic IGF-II production since assays for its measurement are not widely available.

Under gross inspection, the SFTs are generally well-circumscribed and typically 5 - $10 \mathrm{~cm}$ in diameter [3]. Histologically SFTs are diffusely cellular with round to polygonal cells that are tightly packed or syncytial. They have an elaborate branching (staghorn) vasculature. To be classified as malignant, an SFT must be greater than 5 $\mathrm{cm}$ in diameter, have an increased mitotic rate ( $>4$ mitoses per 10 high-power fields), display marked hypercellularity, contain pleomorphic cells and foci of haemorrhage and necrosis [3].

The gold-standard treatment of choice for SFT is a total gross resection. An 80\% 5-year survival is achieved with a total curative resection compared with 50\% 5-year survival with a partial non-curative resection [2]. Chemotherapy treatment of SFT is typically reserved for cases where resection is not possible and has only minimal clinical effectiveness [2].

\section{References}

[1] Thomas, J. and Kumar, S. (2013) Non Islet Cell Tumor Hypoglycaemia. Case Reports in Endocrinology, 2013, Article ID: 308086.

[2] Bokshan, S.L., Doyle, M., Becker, N., Nalbantoglu, I. and Chapman, W.C. (2012) Hepatic Hemangiopericytoma/Solitary Fibrous Tumor: A Review of Our Current Understanding and Case Study. Journal of Gastrointestinal Surgery: Official Journal of the Society for Surgery of the Alimentary Tract, 16, 2170-2176. http://dx.doi.org/10.1007/s11605-012-1947-x

[3] Horvai, A.E. and Link, T.M. (2012) Bone and Soft Tissue Pathology. Elsevier/Saunders, Philadelphia.

[4] Liu, Q., Liu, J., Chen, W., Mao, S. and Guo, Y. (2013) Primary Solitary Fibrous Tumors of Liver: A Case Report and Literature Review. Diagnostic Pathology, 8, 195. http://dx.doi.org/10.1186/1746-1596-8-195

[5] Enzinger, F.M. and Smith, B.H. (1976) Hemangiopericytoma. An Analysis of 106 Cases. Human Pathology, 7, 61-82. http://dx.doi.org/10.1016/S0046-8177(76)80006-8

[6] Pavelic, K., Spaventi, S., Gluncic, V., Matejcic, A., Pavicic, D., Karapandza, N., et al. (1999) The Expression and Role of Insulin-Like Growth Factor II in Malignant Hemangiopericytomas. Journal of Molecular Medicine, 77, 865-869. http://dx.doi.org/10.1007/s001099900068 
Scientific Research Publishing (SCIRP) is one of the largest Open Access journal publishers. It is currently publishing more than 200 open access, online, peer-reviewed journals covering a wide range of academic disciplines. SCIRP serves the worldwide academic communities and contributes to the progress and application of science with its publication.

Other selected journals from SCIRP are listed as below. Submit your manuscript to us via either submit@scirp.org or Online Submission Portal.
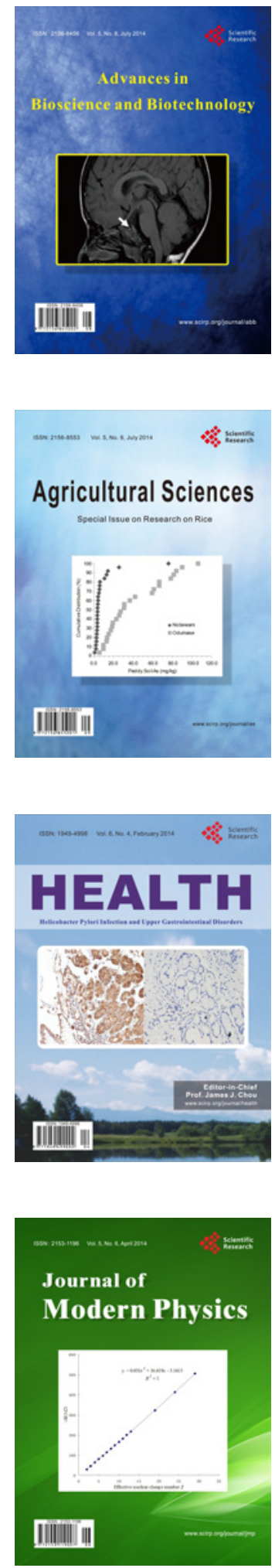
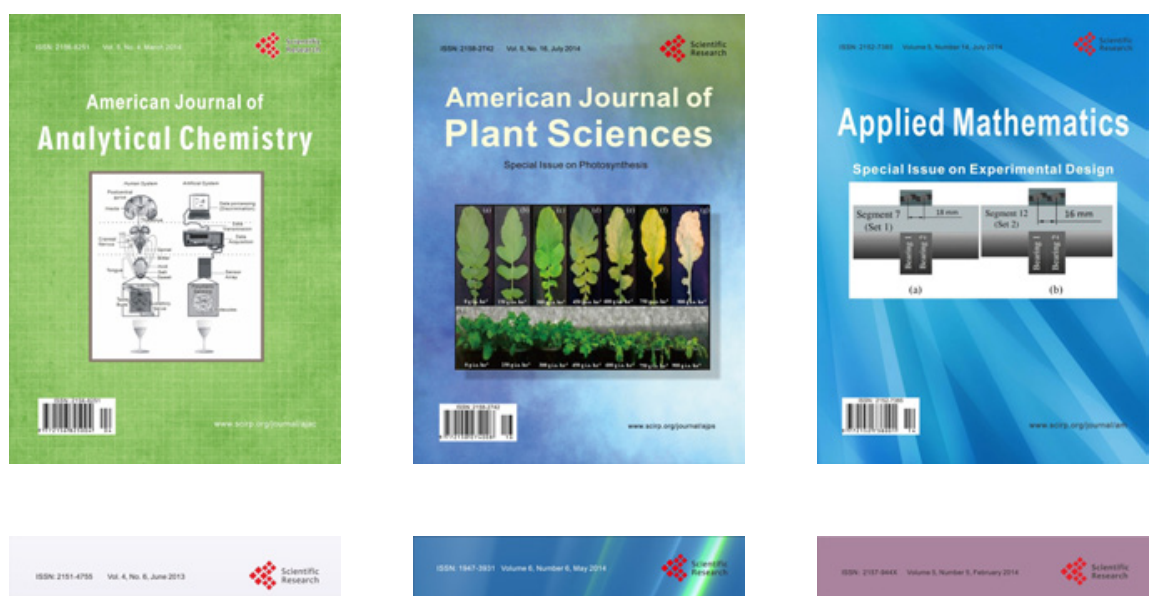

Creative Education
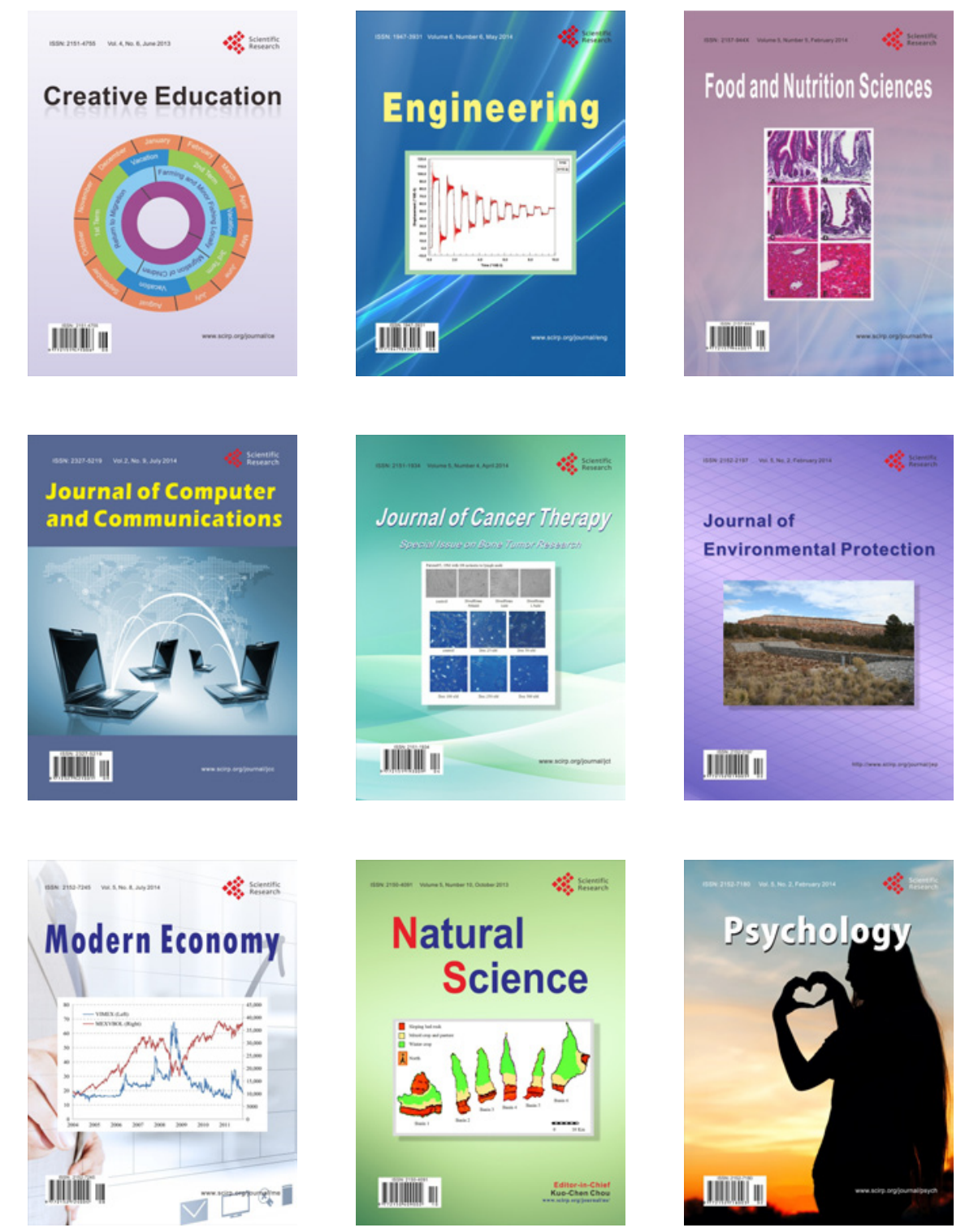